\title{
Incentivising Employment during the COVID-19 Pandemic
}

Phil Lord ${ }^{\mathrm{a} *}$

${ }^{a}$ Faculty of Law, McGill University, Montreal, Canada

* 3644 Peel St, Montreal, Canada, H3A 1W9, 1-514-447-4704,

phil.lord@mail.mcgill.ca 


\section{Incentivising Employment during the COVID-19 Pandemic}

This article considers government responses to unemployment caused by the COVID-19 pandemic. It analyses the two main legislative responses adopted by North American governments: a broadening of access to (un)employment insurance (EI) and the adoption of payroll subsidies for companies. It comparatively and critically assesses these two solutions, to eventually propose an alternative plan. Under this plan, access to EI would be broadened to cover those not traditionally covered by it, such as self-employed workers, contract workers, and those caring for a family member sick from COVID-19 or for a child who is at home due to school and day-care closures. Unemployed workers who have traditionally paid into the EI system would be rewarded through a tax credit. To avoid incentivising temporary layoffs, a payroll subsidy would be adopted. The subsidy would make it as attractive to keep workers on payroll as to lay them off so they can benefit from EI. It would also provide a more faithful picture of unemployment rates during the crisis. The plan would also address broader concerns regarding the unsustainability of public spending during the crisis by limiting access to both temporary layoffs and the payroll subsidy. Large and profitable companies, as well as companies with high revenue or cash reserves, would not be able to temporarily lay their employees off during the crisis or benefit from the subsidy. For companies that face liquidity issues yet are not eligible for the subsidy, short-term, interest-bearing emergency loans would be available.

Keywords: health crisis, coronavirus, COVID-19, private sector, government, virus, public health, employment insurance, unemployment, financial crisis, public law, stimulus, GDP, layoff, business, regulation, subsidy, payroll, taxation

\section{Introduction}

In late 2019 and early 2020, a novel form of coronavirus quickly spread around the world, creating a global health crisis with significant economic consequences. ${ }^{1}$

\footnotetext{
${ }^{1}$ Tedros Adhanom Ghebreyesus, 'WHO Director-General's Opening Remarks at the Media Briefing on COVID-19 - 11 March 2020' (World Health Organization, 11 March 2020) $<$ www.who.int/dg/speeches/detail/who-director-general-s-opening-remarks-at-the-mediabriefing-on-covid-19---11-march-2020> accessed 23 March 2020.
} 
Governments have been struggling to respond to the unique circumstances of an economic slowdown and ostensibly impending recession caused by this global health crisis. $^{2}$

In a typical economic slowdown, certain sectors of the economy will be affected. ${ }^{3}$ The slowdown will gradually spread to other sectors of the economy absent government intervention. ${ }^{4}$ A global health crisis is different. Once a virus spreads around the world, it has the potential to infect an exponentially increasing number of people. ${ }^{5}$ To slow its spread, the only effective solution is an immediate and often indefinite shutdown of most sectors of the economy. ${ }^{6}$ To give but one example that typifies the situation Canadian provinces and American states have faced, the Quebec ${ }^{7}$ government initially banned outdoor gatherings of 250 or more individuals. ${ }^{8}$ The following day, on 13 March 2020, it shut down all schools, day-cares, and universities. ${ }^{9}$

${ }^{2}$ On the latter point, see for example Alexandra Sternlicht, 'Ray Dalio: "We're Heading Into A Great Depression"' Forbes (New York, 8 April 2020) $<$ www.forbes.com/sites/alexandrasternlicht/2020/04/08/ray-dalio-were-heading-into-agreatdepression/?utm campaign $=$ forbes\&utm source $=$ facebook\&utm medium $=$ social\&utm te

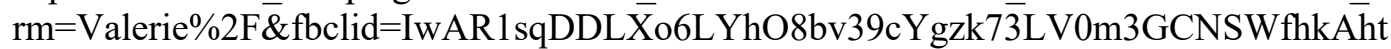
q475fK9c_f-H5LBo\#77f272c97c83> accessed 16 April 2020.

3 See generally Tomoe Moore and Ali Mirzaei, 'The Impact of the Global Financial Crisis on Industry Growth' (2016) 84 The Manchester School 159.

${ }^{4}$ See generally Robert K Rasmussen and David A Skeel Jr, 'Government Intervention in an Economic Crisis’ (2016) 19 University of Pennsylvania Journal of Business Law 7.

${ }^{5}$ On the coronavirus specifically, see Adam J Kucharski and others, 'Early Dynamics of Transmission and Control of COVID-19: A Mathematical Modelling Study' (2020) The Lancet $<$ www.thelancet.com/journals/laninf/article/PIIS1473-3099(20)30144-4/fulltext> accessed 27 March 2020.

${ }^{6}$ Neil M Ferguson and others, 'Impact of Non-Pharmaceutical Interventions (NPIs) to Reduce COVID-19 Mortality and Healthcare Demand' (2020) Imperial College COVID-19 Response Team Working Paper <www.imperial.ac.uk/media/imperialcollege/medicine/sph/ide/gida-fellowships/Imperial-College-COVID19-NPI-modelling16-03-2020.pdf> accessed 27 March 2020.

${ }^{7}$ Quebec is a Canadian province.

8 'La pandémie de la COVID-19: Le gouvernement du Québec diffuse de nouvelles directives à l'intention de la population du Québec' (Gouvernement du Québec, 12 March 2020) $<$ www.quebec.ca/premier-ministre/actualites/detail/le-gouvernement-du-quebec-diffusede-nouvelles-directives-a-l-intention-de-la-population-du-quebec/> accessed 27 March 2020.

9 'La pandémie de la COVID-19 : Le gouvernement du Québec annonce la fermeture des écoles, des cégeps, des universités et des services de garde' (Gouvernement du Québec, 13 
Just over one week later, on 22 March, the government ordered the closure of all businesses that provide non-essential services: malls, restaurants, hair salons, and so forth. Initially expected to end at the earliest on 13 April, ${ }^{10}$ the closure was extended through June. ${ }^{11}$

With these closures, unprecedented numbers of workers have suddenly (at least temporarily) lost their job. In Canada, through the month of March (which only covers the beginning of the crisis), over one million people have lost their job, and over three million people have seen their working hours reduced. ${ }^{12}$ The unemployment rate has climbed from 5.6 per cent to 7.8 per cent - the steepest rise in recorded history. ${ }^{13}$ Women, younger workers, and workers in lower-wage positions are most likely to have been laid off. ${ }^{14}$ In the United States, 6.6 million people lost their job in the first week of April, with a cumulative 16 million people having lost their job as of 9 April $2020 .{ }^{15}$ Just in March, the unemployment rate rose from 3.5 per cent to 4.4 per cent. ${ }^{16}$ Experts

March 2020) <www.quebec.ca/premier-ministre/actualites/detail/le-gouvernement-duquebec-annonce-la-fermeture-des-ecoles-des-cegeps-des-universites-et-des-services/> accessed 27 March 2020.

10 'Pandémie de la COVID-19 - Le Québec sur pause', (Entreprises Québec, 24 March 2020) $<$ www2.gouv.qc.ca/entreprises/portail/quebec/actualites?lang $=\mathrm{fr} \& \mathrm{x}=$ actualites\&e $=328795$ 5177> accessed 8 April 2020.

11 'Réduction au minimum des services et activités non prioritaires', (Gouvernement du Québec) $<$ www.quebec.ca/sante/problemes-de-sante/a-z/coronavirus-2019/fermeture-endroitspublics-commerces-services-covid19/> accessed 8 April 2020.

${ }^{12}$ Matt Lundy, 'Women, Younger Workers Bear Brunt of One Million Job Losses in March' The Globe and Mail (Toronto, 9 April 2020)

$<$ www.theglobeandmail.com/business/economy/article-canada-loses-record-1-millionjobs-as-coronavirus-falloutslams/?fbclid=IwAR37NIfwXgnI_CnlambkW5QFpPv3pXUmplEXSo6wfrI1fsePojaeoLk5ao> accessed 9 April 2020.

13 ibid.

${ }^{14}$ ibid.

${ }^{15}$ Dominic Rushe and Michael Sainato, 'US Unemployment Rises 6.6M in a Week as Coronavirus Takes Its Toll' The Guardian (New York, 9 April 2020) $<$ www.theguardian.com/business/2020/apr/09/us-unemployment-filingscoronavirus\#maincontent> accessed 9 April 2020.

${ }^{16}$ Dominic Rushe, 'US Jobs Report: Unemployment Rose to 4.4 per cent in March After February's 50-Year Low' The Guardian (New York, 3 April 2020) $<$ www.theguardian.com/business/2020/apr/03/us-jobs-report-march-unemploymentcoronavirus $>$ accessed 9 April 2020. 
predict the unemployment rate will reach more than double that of the 2008-09 financial crisis. ${ }^{17}$ It is also worth mentioning that many workers who are out of work are not counted as unemployed, as they are not actively seeking work. ${ }^{18}$ This includes those who have stopped looking for a job and those caring for a child at home due to school closures related to the COVID-19 pandemic (this point is further detailed below).

Governments have had to innovate when responding to this unprecedented situation. Their main concern has ostensibly been ensuring that businesses and individuals are not bankrupted by the crisis and can resume their activities after the pandemic. This article will focus on (un)employment-related North American legislative responses to the COVID-19 pandemic. It will undertake a comparative analysis of the two main government responses to the crisis: subsidising company payrolls and extending unemployment insurance programs to cover those who do not pay into them and are not traditionally covered by them. The article will then propose a program that solves the issues raised by its analysis.

The main issues I raise in my analysis regard the comprehensiveness of the programs enacted by North American governments. My proposed approach seeks to reduce the unsustainable fiscal cost of the current programs (by shifting some of their cost to the private sector), ensure fairness among employed and other individuals, and, most importantly, ensure that companies survive and keep their workers on payroll throughout the crisis.

The next two sections set out the two main responses to the crisis. The following analyses them and proposes my alternative. Finally, I synthesise and conclude.

\footnotetext{
17 ibid.

${ }^{18}$ See for instance Stephen R G Jones and W Craig Riddell, 'The Measurement of Unemployment: An Empirical Approach’ (1999) 67 Econometrica 147.
} 


\section{Bolstering Unemployment Insurance}

The first legislative response adopted by North American governments has been a broadening of access to unemployment insurance, also known as employment insurance and which I hereafter refer to as EI. In Canada, EI is funded solely by employees and employers. Through a payroll tax, they contribute to a system, which then pays out benefits to unemployed workers. General tax revenue is not used to fund the system. ${ }^{19}$ The system has traditionally been reserved to employees, though self-employed workers can choose to register for EI. ${ }^{20}$

In the wake of the COVID-19 pandemic, the Canadian government adopted a number of measures to broaden access to EI. First, it waived the one-week delay to start claiming EI sickness benefits. Second, it adopted the Canada Emergency Response Benefit plan (formerly the Emergency Care Benefit and Emergency Support Benefit plans) at a cost of some 40 billion dollars, ${ }^{21}$ up from an initial 15 billion dollars. ${ }^{22}$ The

Benefit plan was announced as proposed legislation by the Liberal government. It was

${ }^{19}$ The contribution rate for 2020 is 1.58 per cent of earnings up to 54,200 dollars for employees, and 1.4 times the employee rate for employers. '2020 Employment Insurance Premium Rate' (Employment and Social Development Canada) < www.canada.ca/en/employmentsocial-development/programs/ei/ei-list/reports/premium/rates2020.html $>$ accessed 27 March 2020. 'Employment Insurance - Important Notice About Maximum Insurable Earnings for 2020' (Employment and Social Development Canada)

$<$ www.canada.ca/en/employment-social-development/programs/ei/ei-list/eiemployers/2020-maximum-insurable-earnings.html> accessed 27 March 2020.

20 'EI Special Benefits for Self-Employed People: Overview' (Canada Revenue Agency) $<$ www.canada.ca/en/services/benefits/ei/ei-self-employed-workers.html> accessed 27 March 2020.

21 'Government Introduces Emergency Response Benefit' (Department of Finance Canada, 25 March 2020) <www.canada.ca/en/department-finance/news/2020/03/introduces-canadaemergency-response-benefit-to-help-workers-and-businesses.html $>$ accessed 27 March 2020. Patrick Brethour, 'Ottawa's New Emergency Benefit Upends Traditional Employment Insurance Rules' The Globe and Mail (Toronto, 27 March 2020) $<$ www.theglobeandmail.com/business/article-ottawas-new-emergency-benefit-upendstraditional-employment-insurance/> accessed 27 March 2020.

${ }^{22}$ Fatima Syed and Murad Hemmadi, 'Breaking Down Ottawa's \$82-Billion Economic Response Plan' The Logic (Toronto, 18 March 2020) <thelogic.co/news/specialreport/breaking-down-ottawas-82-billion-economic-response-plan-for-covid-19/> accessed 27 March 2020. 
enacted into law shortly thereafter, on 25 March $2020 .{ }^{23}$ The bill was the result of extensive negotiations with all parties. It includes provisions which grant significant powers to the elected minority government, most notably unlimited borrowing. The powers granted in the initial version of the bill were even broader. They were narrowed down to secure the support of the other parties. ${ }^{24}$ Though the bill went through all stages of debate in the House of Commons and Senate, the House was comprised of only 32 Members of Parliament (of the usual 338), as the House has previously voted to suspend its sittings until 20 April. ${ }^{25}$ The bill was passed through unanimous consent. ${ }^{26}$

The Canada Emergency Response Benefit plan extends EI to cover those not traditionally covered under the system, including self-employed workers, contract workers, individuals caring for a child at home due to school and day-care closures, and

${ }^{23}$ Canada, COVID-19 Emergency Response Act, SC 2020, c 5.

${ }^{24}$ Amanda Connolly, 'Trudeau's \$82B Coronavirus Support Package Gets Royal Assent, Officially Passes' Global News (Ottawa, 25 March 2020) $<$ globalnews.ca/news/6728936/coronavirus-canada-emergency-legislation/> accessed 1 July 2020. For an analysis of these emergency powers, see Paul Daly, 'Emergency Economic Powers in Canada: Bill C-13's Crown Corporation' (Administrative Law Matters, 1 April 2020) <www.administrativelawmatters.com/blog/2020/04/01/emergency-economicpowers/> accessed 1 July 2020. On legislation as a tool to effect social change and the regulatory state more generally, see Wim JM Voermans, 'Legislation and Regulation' in Ulrich Karpen and Helen Xanthaki (eds), Legislation in Europe: A Comprehensive Guide For Scholars and Practitioners (Hart Publishing 2017). Absent these provisions, the Canadian government would simply not have had the power to enact its plans. It did not use the Emergencies Act (RSC 1985, c 22, as amended by SC 2001, c 27), which would have granted it additional powers. While a full analysis of this point is beyond the scope of this article, the government likely concluded that the decision to use the Act would have been contested before the courts. Indeed, the Act was largely unnecessary, as each province and territory could declare a state of emergency and take the necessary precautions to slow the spread of the virus.

25 'House of Commons Proceedings: House Reconvenes to Consider COVID-19 Emergency Economic Measures' CPAC (Ottawa, 24 March 2020) <www.cpac.ca/en/programs/house-ofcommons/episodes/66175945/> accessed 1 July 2020.

26 ‘Trudeau’s \$82B Coronavirus Support Package Gets Royal Assent, Officially Passes' (n 24). 
individuals caring for a family member sick from COVID-19. ${ }^{27}$ They are provided with a taxable payment of 2,000 dollars per month, for up to 4 months. ${ }^{28}$

In the United States, the system is similar. Unemployment benefits are funded through payroll taxes. The Internal Revenue Service (the federal taxation agency) levies some of these taxes and provides broad guidelines, but the programs are almost entirely administered by state governments. ${ }^{29}$ The extent and modalities of benefits therefore vary. However, as was the case in Canada, the federal government adopted in its COVID-19 response bill an unprecedented federal program that broadened access to EI benefits to cover those not traditionally covered, such as self-employed and contract workers. ${ }^{30}$ The program provides an additional 600 dollars per week to those already covered by EI systems, and provides the framework for a system that will provide benefits to individuals not covered that mirror those provided by the states. The program also extends, as needed (depending on coverage in individual states), the maximum eligibility period. ${ }^{31}$

\section{Subsidising Payrolls}

The second response adopted by North American governments in light of the unprecedented number of unemployment claims related to the COVID-19 pandemic has been a payroll subsidy. In Canada, this measure was adopted, at least in its current form, much after the beginning of the crisis.

27 'Canada's COVID-19 Economic Response Plan' (Government of Canada) $<$ www.canada.ca/en/department-finance/economic-response-plan.html $>$ accessed 27 March 2020.

${ }^{28}$ ibid.

${ }^{29}$ This is allowed under the Federal Unemployment Tax Act, 26 USC $\S 3301$ and following.

30 'What's in the \$2 Trillion Coronavirus Stimulus Bill' CNN (Washington, 26 March 2020) $<$ cnn.com/2020/03/25/politics/stimulus-package-details-coronavirus/index.html $>$ accessed 2 April 2020. The bill is US, Bill HR 748, CARES Act, 116th Congress, 2020 (signed by the President on 27 March 2020).

${ }^{31}$ ibid. See also Tami Luhby, 'Stimulus Bill Offers $\$ 600$ a Week to the Unemployed for 4 Months' CNN (Washington, 26 March 2020) <www.cnn.com/2020/03/25/politics/senatestimulus-unemployment-benefits-coronavirus/index.html $>$ accessed 16 April 2020. 
Initially in Canada, a budget of 3.8 billion dollars was allocated to subsidise the wages of employees of small businesses. The subsidy covered up to 10 per cent of payroll costs, up to a maximum of 1,375 dollar per employee and 25,000 dollars per company. ${ }^{32}$ It was only available to privately held, Canadian-controlled companies with less than 15 million dollars in assets. ${ }^{33}$ Needless to say, it is hard to think of a 10 per cent subsidy as much of an incentive not to lay off a worker - and therefore keep paying the remaining 90 per cent of her salary. On 27 March, the government increased the subsidy to 75 per cent, for up to 3 months, retroactive to 15 March. $^{34}$ The eligibility criteria were announced three days later, on 30 March. Canadian businesses and nonprofit organisations of all sizes are now eligible for the program if they saw a decrease in revenue of at least 30 per cent. The program covers 75 per cent of payroll costs (salaries), up to 58,700 dollars per employee, for up to 3 months. ${ }^{35}$ It was enacted into law on 11 April. ${ }^{36}$ The Conservative Party (the Official Opposition in the House) joined the minority Liberal government to expedite the process, and debate and vote on the bill in a single day. ${ }^{37}$

In the United States, a somewhat similar result is achieved through a loan program for small businesses. The program calls for 1-per-cent-interest loans and states

\footnotetext{
32 'Canada's COVID-19 Economic Response Plan' (n 27).

33 'Frequently Asked Questions - Temporary Wage Subsidy for Employers' (Canada Revenue Agency) $<$ www.canada.ca/en/revenue-agency/campaigns/covid-19-update/frequentlyasked-questions-wage-subsidy-small-businesses.html\#h2> accessed 27 March 2020.

34 'Prime Minister Announces Support for Small Businesses Facing Impacts of COVID-19' (Justin Trudeau, Prime Minister of Canada, 27 March 2020) < pm.gc.ca/en/news/newsreleases/2020/03/27/prime-minister-announces-support-small-businesses-facing-impacts $>$ accessed 27 March 2020.

35 'The Canada Emergency Wage Subsidy' (Department of Finance Canada) $<$ www.canada.ca/en/department-finance/news/2020/04/the-canada-emergency-wagesubsidy.html $>$ accessed 30 March 2020.

${ }^{36}$ COVID-19 Emergency Response Act, No. 2, SC 2020, c 6. As the sitting suspension mentioned above was still in effect, the House was again comprised of only 32 members

${ }^{37}$ Raisa Patel and John Paul Tasker, 'Parliament Adopts Wage Subsidy Bill as MPs Applaud All-Party Collaboration' CBC News (Ottawa, 11 April 2020) $<$ www.cbc.ca/news/politics/parliament-reconvenes-to-debate-wage-subsidy-bill-1.5529736> accessed 1 July 2020.
} 
that the loan principal amount can be used for expenses beyond payroll. ${ }^{38}$ However, the criteria set by the United States Small Business Administration state that, for the loan to be forgiven, 75 per cent or more of the forgiven portion must have been used for payroll expenses. ${ }^{39}$ This program can be construed as a payroll subsidy. It was likely called a loan program because in the current political climate, with a Republican President and senate majority, grants to companies would be perceived negatively. The program is only applicable to small businesses, under a number of applicable definitions depending on, inter alia, industry - though these definitions often include businesses of up to 500 employees. ${ }^{40}$ It is worth noting that the program exhausted its budget on 13 April. The Administration's website now displays the following message: 'The SBA is currently unable to accept new applications for the Paycheck Protection Program based on available appropriations funding. ${ }^{, 41}$

The next section assesses the two government responses described in this section and the previous one. It proposes potential solutions to the issues it raises, to put forth a more comprehensive plan to combat unemployment related to the COVID-19 pandemic.

\section{Perfecting the Imperfect: A More Comprehensive Plan to Incentivise}

\section{Employment}

The main issues I raise in this section regard the comprehensiveness of the programs enacted by North American governments. My proposed approach seeks to reduce the unsustainable fiscal cost of the current programs (by shifting some of their cost to the private sector), ensure fairness among employed and other individuals, and, most

\footnotetext{
38 'What's in the $\$ 2$ Trillion Coronavirus Stimulus Bill' (n 30); CARES Act (n 30); and 'Paycheck Protection Program' (US Small Business Administration) <www.sba.gov/fundingprograms/loans/coronavirus-relief-options/paycheck-protection-program-ppp $>$ accessed 16 April 2020.

${ }^{39}$ ibid.

${ }^{40}$ ibid.

41 'Paycheck Protection Program’ (n 38).
} 
importantly, ensure that companies survive and keep their workers on payroll throughout the crisis.

I articulate my analysis around three axes. The first subsection argues in favour of a broadening of access to EI, but also that the current plans penalise salaried workers who have traditionally paid into the EI system. It proposes rewarding these workers through a tax credit. The second subsection analyses how EI (and broader access to it) can incentivise unemployment. I argue in favour of payroll subsidies, of an extent commensurate to EI, to incentivise companies to keep their workers on payroll. Finally, subsections three and four focus on how access to both programs should be limited, in order to control government spending during the crisis. I argue that large and profitable companies, as well as those with high revenue or cash reserves, should not be allowed to temporarily lay off their workers during the crisis or benefit from the subsidy. For companies that face liquidity issues yet are not eligible for the programs, I propose the creation of a program of emergency, interest-bearing loans.

\subsection{Rewarding Salaried Workers}

One issue with the current legislative plans is that they punish salaried workers who pay into the EI system. While this was likely not the government's intent, it is the result of the plans' design. In Canada, workers who pay into the traditional EI system are not eligible for the plan. ${ }^{42}$ In the United States, they receive a lower amount. In both countries, workers must use the weeks they have accrued in the traditional EI system. ${ }^{43}$

\footnotetext{
42 'Canada Emergency Response Benefit' (Government of Canada) $<$ www.canada.ca/en/services/benefits/ei/cerbapplication.html?fbclid=IwAR3PVSyJvKW1xhkBb6zcWtV_XnZ6vB88Gggt5NaYUgYd HxgUUeghMhk9ePk> accessed 9 April 2020.

${ }^{43}$ The number of weeks of eligibility is determined based on the number of insurable hours the worker has accumulated and the unemployment rate in their region. 'EI Regular Benefits: How Much You Could Receive' (Government of Canada)
} 
As mentioned above, EI is generally funded through a payroll tax. As such, these workers (and their employers) fund their own benefits. In contrast, the benefits of individuals not traditionally eligible for EI (who receive benefits under the COVID-19 plans) are funded by general tax revenue. Salaried workers eligible for the traditional EI system therefore fund their own benefits (through the payroll tax) as well as the benefits of non-salaried workers under the COVID-19 plans (through income tax).

This result is inequitable. Those who pay into the traditional EI system should not be punished for doing so. There is no sensible policy reason for punishing salaried workers. We have no reason to believe that these workers earn more than contract or self-employed workers, and should therefore shoulder a greater portion of the burden of funding employment benefits. On the contrary, the EI system is an exception to the progressivity principles which imbue our broader tax system. ${ }^{44}$ For instance, as mentioned above, workers and their employers in Canada pay a flat rate of 'insurable earnings,' up to the maximum of 54,200 dollars. The rate is flat - not progressive. Earnings are capped, which means someone earning 300,000 dollars would pay as much into the system as someone making 55,000 dollars. (Benefits are subject to the same cap.)

The most obvious solution would be to cover salaried workers under the COVID-19 plans. These workers would not use up the credit they have accrued in the traditional EI system. This solution would be fairer, as salaried workers would keep the benefits they have paid for through the separate payroll tax and benefit from the COVID-19 plans, which are funded through general tax revenue.

$<$ www.canada.ca/en/services/benefits/ei/ei-regular-benefit/benefit-amount.html $>$ accessed 9 April 2020.

${ }^{44}$ See for instance Michael Smart, 'Finances of the Nation: Taxation of Top Incomes in Canada

- Recent Developments in Rates and Redistribution' (2019) 67 Canadian Tax Journal 349. 
Some could say that this solution is imperfect, as workers are unlikely to avail themselves of the weeks of unemployment benefits they have accrued in the traditional system. Admittedly (and while there is no data on this point), many workers will pay the payroll tax throughout their lives and never be unemployed. The latter is, of course, not a thing to be lamented. And the cap on benefits and contribution rates are surely set in light of the fact that some workers will never claim benefits. Regardless, some will argue that they have paid into the traditional system throughout their career precisely to be safe in a situation like the current one. This argument can call into question the government's solution of extending benefits to all, and imply that benefits should be reserved for those who pay into the system - with others being helped through other means, such as emergency loans or loans repaid through additional taxation.

Within the current framework, workers who pay into the traditional system could receive benefits through that system and concurrently be compensated differently. They would use up the credit they have accrued in the system and be compensated for their non-reliance on the COVID-19 plans, which are funded through general tax revenue. This compensation could most easily take the form of a tax deduction or tax credit. ${ }^{45}$ In both cases, the amount would reflect the value of the benefits under the COVID-19 plans these workers did not avail themselves of. These changes are necessary to ensure fairness among those (mainly employed individuals) who are subject to specific rules through EI and those subject to the new legislative plan, which covers almost everyone. A refundable tax credit might be preferable to a tax deduction,

\footnotetext{
${ }^{45}$ On the distinction between a tax deduction and a tax credit, see generally Emil M Sunley, 'The Choice Between Deductions and Credits' (1977) 30 National Tax Journal 243 and Thomas F Pogue, 'Deductions vs. Credits: A Comment' (1974) 27 National Tax Journal 659 . I give an example illustrating the contrast between deduction and credit in note 47 , below.
} 
as it would ensure even workers who do not pay income tax are compensated. ${ }^{46}$ Furthermore, a tax credit would compensate all workers equally, while a tax deduction would result in differing net benefits depending on the worker's marginal income tax rate. $^{47}$

Regardless of the solution adopted (and even if none is adopted), the Canadian government should remedy the absurd corollary of its current plan that individuals can get a lower amount under the traditional EI system than under the COVID-19 plan. As salaried workers pay EI contributions through their payroll tax and fund the COVID-19 plan through income tax (a plan they cannot currently benefit from), it defies reason that the COVID-19 plan provides a fixed benefit of 2,000 dollars per month to all. Since EI provides a benefit of 55 per cent of a worker's salary, this means that workers making less than approximately 44,000 dollars will get less than 2,000 dollars per month. Even if the government adopts none of the suggestions put forth in this subsection, it should ensure that workers who indirectly pay for both plans do not get a lower benefit payment than those who only pay for one.

\subsection{Incentivising Work, Not Unemployment}

Warren Buffet once said, '[I]ncentives have terrific power.' He was speaking of the 2016 scandal involving Wells Fargo, an American bank of which his holding company is the largest shareholder. ${ }^{48}$ The bank's employees, rewarded by the bank's commission

${ }^{46}$ Lily L Batchelder, Fred T Goldberg Jr and Peter R A Orzag, 'Efficiency and Tax Incentives: The Case for Refundable Tax Credits' (2006) 59 Stanford Law Review 23. A refundable tax credit is paid to an individual even when they have no tax liability.

${ }^{47}$ Sunley (n 45) 243. Tax credits reduce an individual's tax liability. A 300-dollar tax credit reduces a 3,000-dollar tax liability to 2,700 dollars. In contrast, a tax deduction is applied to taxable income. A 3,000-dollar credit reduces a taxable income of 50,000 dollars to 47,000 dollars. The latter amount is then taxed. The tax savings are equal to the individual's marginal tax rate multiplied by the difference (3,000 dollars).

${ }^{48}$ Maggie McGrath, 'Warren Buffett On Wells Fargo Fiasco: 'It's A Great Bank That Made A Terrible Mistake'" Forbes (New York, 11 November 2016) 
structure, unlawfully opened millions of credit and banking accounts on behalf of the bank's consumers. The bank had to pay hundreds of millions in fines. ${ }^{49}$ Its incentive structure had caused institutionalised fraud. Buffet is correct to state that incentives are exceedingly powerful, especially in business. So it is worth asking, what are the programs proposed by our governments in light of the COVID-19 pandemic incentivising $?^{50}$

The initial government response has been a broadening of access to EI. This is an intuitive and arguably necessary response. If people lose their job, there needs to be a program to ensure that they do not go bankrupt. However, simply broadening eligibility for EI is, in itself, unhelpful in addressing the broader consequences of a slowing economy. Helping those who lose their job does nothing to ensure that more people do not lose their job. Worse yet, it can do the opposite.

The relationship between EI and unemployment is in no way mystical. Research has long shown that EI can incentivise unemployment. ${ }^{51}$ Access to EI is likely responsible for approximately half of temporary layoffs. ${ }^{52}$ This relationship is quite intuitive, especially regarding temporary layoffs. Temporary layoffs are permitted, with

<www.forbes.com/sites/maggiemcgrath/2016/11/11/warren-buffett-on-wells-fargo-fiascoits-a-great-bank-that-made-a-terrible-mistake/\#753b1ac73304> accessed 12 April 2020.

${ }^{49}$ Maggie McGrath, 'Elizabeth Warren To Wells CEO Stumpf: You Should Resign And Face Criminal Investigation' Forbes (New York, 20 September 2016) $<$ www.forbes.com/sites/maggiemcgrath/2016/09/20/wells-fargo-ceo-john-stumpf-toapologize-to-senate-banking-committee/\#67be5c383aab> accessed 12 April 2020.

${ }^{50}$ On incentives in legislation and regulation more generally, see Richard H Taler and Cass $\mathrm{R}$ Sunstein, Nudge: Improving Decisions about Health, Wealth, and Happiness (Yale University Press 2008). Regarding the pandemic more specifically, see for instance Phil Lord, 'The Social Perils and Promise of Remote Work' (2020) 4 Journal of Behavioral Economics for Policy 63.

${ }^{51}$ See for instance Martin Feldstein, 'Temporary Layoffs in the Theory of Unemployment' (1976) 84 The Journal of Political Economy 937 and Robert H Topel, 'On Layoffs and Unemployment Insurance' (1983) 73 American Economic Review 541.

${ }^{52}$ Martin Feldstein, 'The Effect of Unemployment Insurance on Temporary Layoff Unemployment' (1978) 68 American Economic Review 834. 
varying conditions, under North American legal regimes. ${ }^{53}$ They allow companies to lay off workers during difficult economic times, and rehire them later on. If the layoff meets the statutory conditions, the employment relationship is suspended (not terminated). While the employee is temporarily laid off, she can apply for EI benefits. ${ }^{54}$ This creates an incentive for companies to lay off employees in difficult times: keeping an employee on payroll during those times means choosing to pay a portion of the employee's salary that would otherwise be paid by the EI system.

It would be naïve to suggest that governments are unaware of the relationship between EI and unemployment. It is likelier that governments have made a policy decision to nonetheless allow access to EI and temporary layoffs. First, regardless of the measures taken to avoid layoffs (which I will argue are insufficient and incomprehensive), some individuals will be laid off, especially during economic slowdowns. These individuals need to be provided for. Second, temporary layoffs can be a vital tool to manage systemic risk, shorten and mitigate economic slowdowns, and ensure the survival of companies during difficult economic times. ${ }^{55}$ Indeed, many businesses do not have the financial flexibility to survive a severe economic downturn. Small businesses generally only have sufficient liquidity to fund four or fewer weeks of

${ }^{53}$ See for instance Employment Standards Act, SO 2000, c 41, s 56 (in Ontario, Canada); An Act Respecting Labour Standards, CQLR c N-1.1, s 82-85 (in Quebec, Canada); and Employment Standards Code, RSA 2000, c E-9, s 62-64 (in Alberta, Canada). The statutes generally set out the maximum duration of the temporary layoff, as well as the percentage of an employee's work that must be cut for a layoff to exist.

${ }^{54}$ See for example 'EI Regular Benefits: Eligibility' (Government of Canada) $<$ www.canada.ca/en/services/benefits/ei/ei-regular-benefit/eligibility.html $>$ accessed 13 April 2020.

${ }^{55}$ On temporary layoffs and their prevalence and purposes more generally, see Martin Feldstein, 'The Importance of Temporary Layoffs: An Empirical Analysis' (1975) 3 Brookings Papers on Economic Activity 725; Martin Feldstein, 'Temporary Layoffs in the Theory of Unemployment' (n 51); and Kostas G Mavromaras and Chris D Orme, 'Temporary Layoffs and Split Population Models' (2004) 19 Journal of Applied Econometrics 49. 
operating costs. ${ }^{56}$ A downturn can bankrupt these businesses. Furthermore, businesses can face liquidity problems, especially during a downturn, ${ }^{57}$ even if their financial position is strong. ${ }^{58}$ Temporary layoffs can be a way for governments to provide financial flexibility on a key financial cost (payroll). Other operating costs may be less flexible, and without the purview of government control or measures.

That is not to say that unbridled access to EI and to temporary layoffs is a good thing. EI should be a last resort, and governments should dedicate the majority of their efforts to proactively preventing layoffs, rather than reacting to them. The Canadian government's response to unemployment caused by the COVID-19 pandemic typifies these points. As mentioned in section 2, the government initially responded by broadening access to EI, extending benefits to, among others, the self-employed and those caring for child at home or a family member who contracted COVID-19. The adoption of these measures likely contributed to the unprecedented number of individuals becoming unemployed. The initial plan also called for a 10 per cent wage subsidy, which, as mentioned previously, can hardly be construed as a disincentive to layoffs. It is only two weeks later that the government announced a 75 per cent wage subsidy, to prevent layoffs.

56 'Cash is King: Flows, Balances, and Buffer Days: Evidence from 600,000 Small Businesses' (JP Morgan Chase \& Co Institute, September 2006), 6

$<$ www.jpmorganchase.com/corporate/institute/document/jpmc-institute-small-businessreport.pdf $>$ accessed 23 March 2020. This report finds that the median small business can fund 27 days of operating costs. Only 25 per cent of businesses can support more than 62 days of operating costs, while 25 per cent can fund fewer than 13.

${ }^{57}$ Banks generally tighten lending requirements during economic downturns. Simon H Kwan, 'Financial Crisis and Bank Lending' (2010) Federal Reserve Bank of San Francisco Working Paper No $11<$ ssrn.com/abstract=1571595> accessed 23 March 2020.

${ }^{58}$ On these concepts more generally, see Roger EA Farmer, 'What is a Liquidity Crisis?' (1988) 46 Journal of Economic Theory 1. For a more vulgar exposition, see 'Solvency Ratio vs. Liquidity Ratios: What's the Difference?' (Investopedia, 27 August 2019) $<$ www.investopedia.com/ask/answers/040115/what-are-differences-between-solvencyratios-and-liquidity-ratios.asp > accessed 23 March 2020. 
Unfortunately, as mentioned above, by the time the expanded wage subsidy program was announced, hundreds of thousands of Canadians had been laid off, and millions more had seen their working hours reduced. Some companies opted to rehire the workers they had temporarily laid off. WestJet rehired some 6,400 workers, and Air Canada rehired some $16,500 .{ }^{59}$ However, many companies undoubtedly opted not to rehire their employees, especially if these employees had begun receiving benefits by the announcement.

In the current context, a wage subsidy is preferable to a broadening of access to EI, i.e. keeping workers on payroll is preferable to temporarily laying them off. In both cases, the government is bearing the cost of supporting employees during a time of crisis. (The subsidy is, as it should be, approximately equivalent to the amount covered by EI. $)^{60}$ It is more efficient for employees to be kept on payroll than to be laid off and have to request government benefits. It ensures that employers keep funding all of these employees' fringe benefits, such as group insurance and pension plans. Keeping these workers employed also offers a more faithful picture of national unemployment. Workers who are temporarily laid off during a time of crisis are only temporarily unemployed. If they are kept on payroll, they are not counted as unemployed in national unemployment statistics. This provides a more faithful picture of unemployment, by counting as unemployed only those who have permanently lost their job due to a

\footnotetext{
${ }^{59}$ Sean Boynton, 'Coronavirus: Westjet to Rehire Nearly 6,400 Workers Through Federal Wage Subsidy' Global News (Vancouver, 9 April 2020) $<$ globalnews.ca/news/6798388/coronavirus-westjet-wage-subsidy/> accessed 13 April 2020. Pete Evans, 'Air Canada to Rehire 16,500 Laid-Off Workers With Help of Federal Government's Wage Subsidy' CBC News (Toronto, 8 April 2020) $<$ www.cbc.ca/news/business/air-canada-hiring-wage-subsidy-1.5525926> accessed 13 April 2020.

${ }^{60}$ That being so, introducing the subsidy at the beginning of the crisis in Canada would have been crucial. If the benefits under EI and the subsidy are roughly equivalent, employers will presumably do what requires the least effort. For workers on payroll, that means keeping them on. For workers who already receive benefits under unemployment plans by the announcement, it may mean not rehiring them until the end of the crisis.
} 
cyclical downturn in the economy. This more faithful picture, which will inevitably result in lower unemployment figures, will likely in turn limit market panic, preventing a vicious cycle that can quickly turn a downturn into a recession. ${ }^{61}$ Finally, keeping workers on payroll will ostensibly make it easier for the economy to reopen and grow once the pandemic, and its business shutdowns, are over.

The wage subsidy therefore mitigates the various concerns regarding access to EI raised in this subsection. It removes the incentive for employers to lay off their employees, as employers are no longer subsidising a portion of their salary that would otherwise be covered by the EI system. Furthermore, it provides the financial flexibility employers need to survive a financial crisis by taking on one of their major costs (payroll cost) - like temporary layoffs do, but with the added benefits mentioned here. A comprehensive plan to combat unemployment during the pandemic should, however, do more than remove these perverse incentives. It should address the cost allocation between governments and private actors, limiting access to the various programs mentioned in this and the previous subsections.

\subsection{Limiting Recourse to Layoffs in Times of Crisis}

Global pandemics are expensive. Extremely expensive. As of 27 March, the budget allocated to respond to the COVID-19 pandemic in Canada was 202 billion Canadian dollars (65 billion in loans, 85 billion in tax deferrals, and 52 billion in direct assistance). ${ }^{62}$ This represents some 10 per cent of GDP. ${ }^{63}$ This budget excludes the

\footnotetext{
${ }^{61}$ Allan P Layton and Anirvan Banerji, 'What Is a Recession?: A Reprise' (2003) 35 Applied Economics 1789, 1792.

${ }^{62}$ Brian DePratto, 'Additional Federal COVID-19 Response Measures' (TD Bank, 27 March 2020) <economics.td.com/additional-covid19-measures> accessed 27 March 2020.

63 'Gross Domestic Product (GDP) at Basic Prices, by Industry, Monthly, Growth Rates (X 1,000,000)' Statistics Canada

$<$ www150.statcan.gc.ca/t1/tb11/en/tv.action?pid=3610043402> accessed 27 March 2020.
} 
wage subsidy, which is expected to significantly increase it. ${ }^{64}$ In the United States, the stimulus package is worth 2.2 trillion US dollars, ${ }^{65}$ nearly triple the amount injected into the economy through the 2008 recession. ${ }^{66}$ The stimulus package also represents approximately 10 per cent of GDP. ${ }^{67}$ These amounts only cover the shutdown period. They do not include any measures to reboot the economy once the isolation period ends. Many have therefore estimated that a capital injection of at least the same size will be necessary to get the economy back on track. ${ }^{68}$ We recently learned that American elected officials are already working on another such stimulus bill. ${ }^{69}$

Regardless of one's political leanings, this level of spending can hardly be considered sustainable. It dwarfs the level of spending incurred during the 2008

64 'Government Announces Details of the Canada Emergency Wage Subsidy to Help Businesses Keep Canadians in their Jobs' (Department of Finance Canada, 1 April 2020)

$<$ www.canada.ca/en/department-finance/news/2020/04/government-announces-details-ofthe-canada-emergency-wage-subsidy-to-help-businesses-keep-canadians-in-theirjobs.html > accessed 2 April 2020.

${ }^{65}$ Clare Foran and others, 'Trump Signs Historic \$2 Trillion Stimulus After Congress Passes It Friday', $C N N$ (Washington, 27 March 2020)

<www.cnn.com/2020/03/27/politics/coronavirus-stimulus-house-vote/index.html> accessed 2 April 2020.

${ }^{66}$ Andrew Clark, 'Paulson Abandons Plans to Buy up America's Toxic Mortgage Assets' The Guardian (New York, 13 November 2008)

$<$ www.theguardian.com/business/2008/nov/13/harry-paulson-banking-rescue-mortgage > accessed 2 April 2020. The bill is US, Bill HR 1424, Emergency Economic Stabilization Act of 2008, 110th Congress, 2008 (enacted 10 March 2008).

67 'Gross Domestic Product' (Bureau of Economic Analysis (US Department of Commerce)) $<$ www.bea.gov/data/gdp/gross-domestic-product> accessed 2 April 2020.

${ }^{68}$ See for instance Dion Rabouin, 'When \$2.2 Trillion Is Not Enough' (Axios, 26 March 2020) $<$ www.axios.com/coronavirus-stimulus-bill-what-it-does-b4fa6c4d-6e45-4d15-8089d51c655bc1c9.html> accessed 27 March 2020; CNN, 'Bill Gates Outlines What He Thinks World Is Learning About Pandemics' (YouTube, 27 March 2020) $<$ www.youtube.com/watch? $=$ =iNLiUN017ws $>$ accessed 28 March 2020, 0m:50s and Canada, Office of the Parliamentary Budget Officer, Scenario Analysis: COVID-19 Pandemic and Oil Price Shocks (2020) 10.

${ }^{69}$ Richard Cowan and David Morgan, 'U.S. Senate Passes One Coronavirus Aid Package While Working on Another' Reuters (Washington, 18 March 2020)

$<$ www.reuters.com/article/us-health-coronavirus-usa-congress/u-s-senate-passes-onecoronavirus-aid-package-while-working-on-another-idUSKBN2151FB $>$ accessed 23 March 2020 and Ella Nilsen, 'What We Know About the Fourth Coronavirus Relief Bill' Vox (Washington, 3 April 2020) <www.vox.com/2020/4/3/21206931/what-we-knowabout-congress-fourth-coronavirus-bill $>$ accessed 10 April 2020. 
recession, the worst financial crisis in almost a century. ${ }^{70}$ This level of spending will cause an explosion of sovereign debt around the world. In that context, it is vital to add a yet missing link to our response to unemployment during the COVID-19 crisis: measures to control cost and restrict access to various programs.

We reach a different outlook in our analysis. This subsection and the next analyse not which government response to the crisis is best (as analysed in the last 2 subsections) but rather who should benefit from the programs set forth in the prior 2 subsections.

Crucial to a sustainable response is limiting recourse to temporary layoffs during pandemics such as this one. I analysed above how the EI system, and greater access to it, can incentivise unemployment. I nonetheless argued for a broadening of access to EI to those not traditionally covered by it, subject to proper compensation for those who have paid into the system. I have also argued that a payroll subsidy should be adopted to limit the incentive for companies to lay off their workers so they can avail themselves of EI benefits. I, nonetheless, do not believe that all companies should benefit from either measure.

As a cost-control mechanism, large and profitable companies should be prevented from temporarily laying off their workers and should not have access to payroll subsidies. ${ }^{71}$ (I address the latter point in the next subsection.) It is worth emphasising that I am referring here only to temporary layoffs. I do not envision a world where companies need to ask governments for permission before laying off their

\footnotetext{
${ }^{70}$ Michael D Bordo and Harold James, 'The Great Depression Analogy' National Bureau of Economic Research Working Paper No 15584 (2009) < ssrn.com/abstract=1522373> accessed 10 April 2020, 1-3.

${ }^{71}$ While the United States has limited eligibility for the payroll subsidy to small businesses, the definition is, as mentioned above, quite broad and often includes companies of up to 500 employees. Furthermore, the United States has not concurrently limited access to temporary layoffs.
} 
workers. Rather, I am arguing that temporary layoffs, a legislative device ${ }^{72}$ companies can use to face difficult times, should only be available to companies that truly need them. As a corollary, the state should not pay, in the form of EI benefits, for large and profitable companies to move their workers off payroll for a limited period of time, especially when they can do so for purely opportunistic or arbitrary reasons.

Companies of all sizes would still be able to permanently lay off their workers, including for reasons related to the COVID-19 pandemic or its economic consequences. However, they would then be subject to the employment law regime. For instance, they might need to make severance payments, face wrongful dismissal lawsuits, or honour pension and various other obligations. As mentioned above, temporary layoffs are a middle road between dismissal and employment. They allow companies dismiss an employee only temporarily - without being subject to the consequences just mentioned. During that period, the employee can claim EI benefits. I am arguing in favour of removing this option for large and profitable companies, at least in times of crisis. Given the consequences that piggyback a permanent layoff, it is highly unlikely that companies would choose to permanently lay off their workers instead, only to rehire them later on. Additionally, workers of large and profitable companies are most likely to have pension and other long-term benefits that make it onerous to dismiss them.

The method to determine which companies to exclude can be debated. To begin, highly profitable companies should be excluded. It would be sensible to focus on the level of profitability, i.e. on profitability relative to revenue or to the number of workers. Additionally, for a more faithful picture of profitability (especially of companies with a cyclical business model or which are significant affected by an economic downturn),

\footnotetext{
${ }^{72}$ In Canada, see for instance Employment Standards Act, SO 2000, c 41, s 56 (in Ontario); An Act Respecting Labour Standards, CQLR c N-1.1, s 82-85 (in Quebec); and Employment Standards Code, RSA 2000, c E-9, s 62-64 (in Alberta).
} 
profitability should be assessed over a period of five or more years, which encompasses a full growth cycle. Companies with high revenue and cash reserves, yet which are not highly profitable, should ostensibly also be excluded. This decision would reflect the fact that profitability may not be the priority for all firms. While public companies are generally keen to maximise their bottom lines, some may not be. Profit means taxation, so some companies may find reinvesting in research and development (R\&D) or expansion to be a more sensible use of their capital. For instance, Amazon, one of the largest companies in the world, has historically reinvested heavily in growth and R\&D, which has led to consistently low or negative net margins. ${ }^{73}$ This is also often true for private companies, which may find tax mitigation more important than profit maximisation. ${ }^{74}$

Excluding certain companies from temporary layoff provisions therefore allows governments to begin to ensure that spending during the crisis is sustainable. Furthermore, it helps ensure that they can provide for those who will still have to rely on the system during the crisis, such as workers not traditionally covered by EI and workers who permanently lose their job. This measure is essentially a cost allocation measure and, given the current level of spending, a necessary one.

\subsection{Phasing Out Subsidies}

Much of the same argument can be made regarding payroll subsidies. I have argued above in favour of payroll subsidies as a way to provide relief to companies, in magnitude similar to EI, without incentivising them to temporarily lay off their

\footnotetext{
${ }^{73}$ Lina M Khan, ‘Amazon's Antitrust Paradox' (2017) 126 Yale Law Journal 710.

${ }^{74}$ See generally Lynn Stout, The Shareholder Value Myth: How Putting Shareholders First Harms Investors, Corporations, and the Public (Berrett-Koehler 2012) and Lynn Stout, 'Corporations Don't Have to Maximize Profits' The New York Times (New York, 16 April $2015)<$ www.nytimes.com/roomfordebate/2015/04/16/what-are-corporations-obligationsto-shareholders/corporations-dont-have-to-maximize-profits> accessed 16 April 2020.
} 
employees. However, just like access to temporary layoffs, access to the subsidy should be restricted to companies that need it the most. Since the subsidy essentially replaces EI for workers kept on payroll instead of temporarily laid off, the same caveats apply.

First, the methods of excluding companies from the subsidy should be the same as those for excluding them from the access to temporary layoffs. Second, as mentioned above, restricting access is necessary to control government spending related to the pandemic. It also helps ensure that the government can provide benefits to those who will rely on the system, either not being traditionally covered by it or permanently losing their job.

A concern arises regarding companies that would be ineligible for either measure, yet face short-term liquidity issues. I mentioned above that even solvent companies can face liquidity problems. Even with a strong balance sheet, companies may be unable to borrow. This is especially likely to happen during a financial crisis, as lenders tighten borrowing requirements or are altogether unwilling to lend.

More crudely, companies may have caused their liquidity issues by distributing profits through dividend payments or stock buybacks. This brings us to an age-old debate. Wanting to save jobs can lead governments to bail out companies that face liquidity problems. But it also creates an expectation that they will do so in the future, implicitly and perversely encouraging companies to engage, once the crisis is over, in the very behaviour that caused their issues. ${ }^{75}$ This latter point leads me to believe that

\footnotetext{
${ }^{75}$ For these reasons, some have argued that companies should not be bailed out. 2012 presidential candidate Mitt Romney argued against President Barack Obama's bailout of the automotive industry following the 2008 financial crisis, Mitt Romney, 'Let Detroit Go Bankrupt' The New York Times (Boston, 18 November 2008) <www.nytimes.com/2008/11/19/opinion/19romney.html> accessed 16 April 2020. Romney believed the companies should have undergone a managed bankruptcy to address their financial and managerial issues. More recently, some have argued that airlines, which face peculiarly serious challenges related to the COVID-19 pandemic, should not be bailed out since they spent much of their earnings on dividends payments and stock buybacks, Joseph Zeballos-Roig, 'Airlines Are Begging for a Bailout, but They've Used 96\% of
} 
the right solution is not a bail out. It is not a grant, but a loan. However, help is indeed necessary. Regardless of how much we might disagree with certain corporate behaviour, ideological positions can cause bankruptcies and job losses. In times of crisis, companies may simply be unable to get liquidity elsewhere.

I suggest that we offer emergency, interest-bearing loans to companies that encounter these challenges. In creating these loans, we would recognise the fact that some companies would be bankrupted by the crisis absent government help. The loans would be interest-bearing, to ensure a fair return to the taxpayer and to avoid creating an incentive for companies to face the same liquidity issues in the future. The interest rate and repayment schedule should be set to ensure that we avoid creating this incentive and that the loans are less advantageous than those companies can obtain privately. The latter point would underscore that these are last-resort, emergency facilities.

\section{Conclusion: Putting It All Together}

In this article, I have analysed the two main measures adopted by North American governments to combat unemployment related to the COVID-19 pandemic: payroll subsidies and a broadening of access to employment insurance. I critically analysed these responses, to offer a more comprehensive alternative. I articulated my analysis around three axes. First, I argued in favour of a broadening of access to EI, while arguing that the current plans penalise salaried workers who have traditionally paid into the EI system. I proposed rewarding these workers through a tax credit. Then, I

Their Cash Flow on Buybacks Over the Past 10 Years. It Highlights an Ongoing Controversy Over How Companies Have Been Spending Their Money.' Business Insider (New York, 17 March 2020) <markets.businessinsider.com/news/stocks/airline-bailoutcoronavirus-share-buyback-debate-trump-economy-aoc-2020-3-1029006175> accessed 16 April 2020 and Adam Levine-Weinberg, "Airlines' Didn't Waste All Their Cash Flow on Share Buybacks: American Airlines Did' (The Motley Fool, 25 March 2020) $<$ www.fool.com/investing/2020/03/25/american-airlines-waste-cash-flow-sharebuybacks.aspx $>$ accessed 16 April 2020. 
analysed how EI (and broader access to it) can incentivise unemployment. I argued in favour of payroll subsidies, of an extent commensurate to EI, as an incentive for companies to keep their workers on payroll. Finally, I considered how access to both programs should be limited to control government spending during the crisis. I argued that large and profitable companies, as well as those with high revenue or cash reserves, should be disallowed to temporarily lay off their workers during the pandemic or benefit from the subsidy. I also considered the problem of companies that face liquidity issues yet are not eligible for the programs by proposing the creation of a program of emergency, interest-bearing loans.

Overall, the main issue with the current North American government approaches is their reactionary nature and lack of comprehensiveness. Governments are understandably concerned with ensuring that people do not lose their home due to the pandemic and that businesses do not permanently shut down. They have been pressed to quickly find new tools to react to the unique circumstances surrounding the economic consequences of a global health crisis. The two main solutions adopted to combat unemployment are commendable. They work. The missing link is a more comprehensive approach, one that controls cost to ensure that benefits can perennially be provided to those who need them most and that prevents the wealthiest and largest companies from unnecessarily getting outsized benefits from the programs. Thoughtful design of government programs, even in a time of crisis, is vital. It can ensure that these programs, while helping the many who need help most, are not also vectors that further entrench existing inequality.

The author wishes to acknowledge Lydia Saad for her thoughtful comments and attentive proofreading of this article, as well as the editors of this special issue and an anonymous 
reviewer for their helpful guidance and comments. The author also wishes to thank Lawrence David for bringing the call for papers to his attention. The author admires the guest editors and the many other scholars who heeded the call to serve and contribute to the vital conversation on how best to respond to the COVID-19 pandemic. A generous grant from Canada's Social Sciences and Humanities Research Council helped the author revise this article. 